\title{
Growth and mortality estimates of Sardinella brasiliensis in the southeastern brazilian bight
}

\author{
Maria Cristina CERGOLE ${ }^{1}$ \& Helio VALENTINI ${ }^{2}$
}

${ }^{1}$ Instituto Brasileiro do Meio Ambiente e dos Recursos Naturais Renováveis (IBAMA)

(Alameda Tietê, 637 - Cerqueira Cesar, 01417-020 Sāo Paulo, SP, Brasil)

2 Instituto de Pesca da Secretaria da Agricultura do Estado de São Paulo

(Avenida Francisco Matarazzo, 455 - 05031-900 São Paulo, SP, Brasil).

- Abstract: Length frequency analisys were applied for sardine data collected from commercial catches throughout the southeastern Brazilian coast in 1977-1987. Age/length keys were obtained by otolith ring countings and utilized to transform length into age composition. Growth parameters were estimated by the von Bertalanffy growth equation using age and length data for each year and for all the period of investigation. The mean growth parameters for the entire period were estimated as $\mathrm{L}_{\infty}=271 \mathrm{~mm}$ and $\mathrm{K}=0.59 \mathrm{year}^{-1}$. Instantaneous total mortality (Z) coefficients per year were estimated using catch curves and methods based on the mean length of the fish caught. Total mortality rate for the entire period was obtained through the average of the annual values. Natural mortality (M) was estimated using the Pauly's empirical equation (1980a), and fishing mortality (F) by the difference between total and natural mortality values. The results were $\mathrm{Z}=3.6 \mathrm{year}^{-1} ; \mathrm{M}=0.96$ year ${ }^{-1}$; and $\mathrm{F}=2.6$ year $^{-1}$.

- Resumo: Estudo sobre o crescimento e a mortalidade de Sardinella brasiliensis, da costa sudeste do Brasil, foi realizado para o período 1977 a 1987. As análises foram efetuadas a partir de dados existentes sobre distribuiçōes de freqüência de comprimento de amostras da captura comercial. Chaves idade/comprimento, construidas a partir de leitura de anéis de crescimento em otólitos, dentro do Programa Integrado de Estudos Biologicos sobre a Sardinha - PIEBS, foram utilizadas para transformar as distribuiçes de comprimento em idade. Os parâmetros de crescimento da equaçāo de von Bertalanffy foram estimados, anualmente e para o período como um todo, a partir de métodos que utilizam dados de idade e comprimento. Os parâmetros médios encontrados para o período foram: $\mathrm{L}_{\infty}=271$

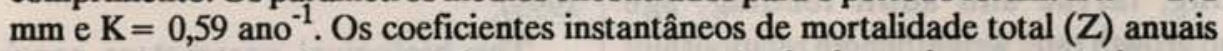
foram calculados pelas curvas de captura e por métodos baseados no comprimento médio dos indivíduos nas capturas. A mortalidade total para todo o período foi obtida pela média dos valores anuais. O coeficiente instantâneo de mortalidade natural (M) foi estimado pela equaçāo empírica de Pauly (1980a), usando um fator de correção de 0,8 para clupeoides, e o coeficiente instantâneo de mortalidade por pesca $(\mathrm{F})$, pela diferença entre a mortalidade total e a natural. Os valores encontrados foram: $\mathrm{Z}=3,6 \mathrm{ano}^{-1}, \mathrm{M}=0,96 \mathrm{ano}^{-1} \mathrm{e} F=2,6 \mathrm{ano}^{-1}$.

- Descriptors: Growth, Mortality, Catch, Sardinella brasiliensis, SW Atlantic, Brazil, Brazilian Bight.

- Descritores: Crescimento, Mortalidade, Captura, Sardinella brasiliensis, Atlântico Sul Ocidental, Brasil, Costa sudeste.

\section{Introduction}

Among the economically important pelagic species in Brazil, the Brazilian sardine, Sardinella brasiliensis, is the one that undergoes strong fishing effort of the commercial fleet. As any clupeoids, the exploitation of this species is characterized by instability of the total catch. Recently, total landing of this species along the southeastern Brazilian coast has experienced a sharp decline resulting in considerable impacts on all sectors of the fishing industry.

Fishing of the Brazilian sardine takes place along the coast of Brazil between the Cape São Tomé $\left(22^{\circ} \mathrm{S}\right)$ and the 
Cape Santa Marta Grande ( $28^{\circ} 30^{\prime}$ S) up to the depth of $70 \mathrm{~m}$ (Fig. 1).

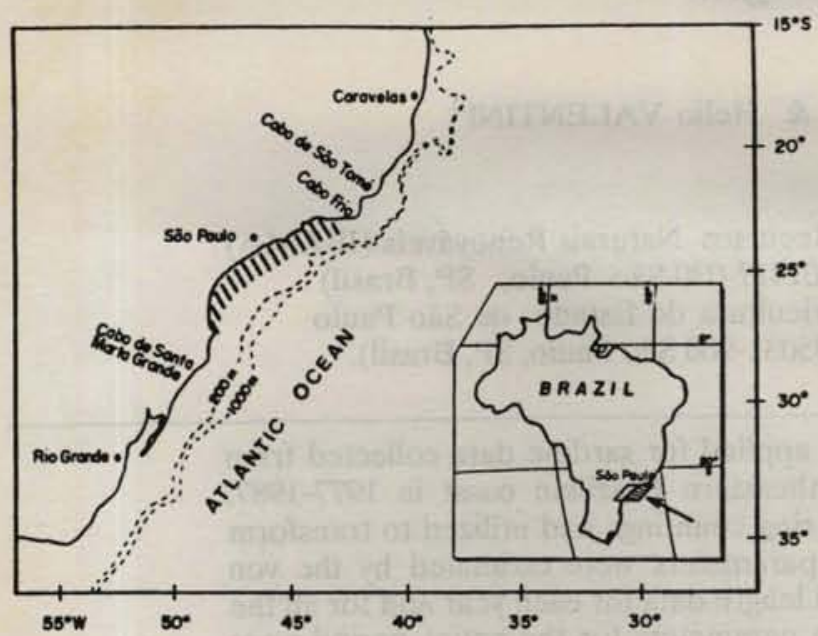

Fig. 1. Fishing area of the Brazilian sardine, Sardinella brasiliensis.

Biological data on S. brasiliensis obtained until 1988 were summarized by Saccardo \& Rossi-Wongtschowski (1991). After this review, some scientific studies were carried out by Matsuura (1988, 1990); Bakun \& Parrish (1990); Spach (1990), Ekau \& Matsuura (1991); Rossi-Wongtschowski \& Saccardo (1991); Lin (1992); and Matsuura et al. (1992).

These studies provided information on: distribution and abundance of eggs and larvae; growth and survival rates of larvae; maturity and fecundity; area, season and type of spawning; larvae and adult feeding; age determination and growth rate; weight/length relationship; sex ratio and mortality estimate by indirect methods.

Growth parameters have already been estimated for sardine, both by length frequency distribution (Richardson et al.; 1960; Santos \& Fratzen, 1965; Matsuura, 1977, 1983; Rijavec et al., 1977) and by growth rings reading in scale (Richardson et al., 1960) and in otolith (Rossi-Wongtscowski et al., 1982; Vazzoler et al., 1982, 1987; Saccardo et al., 1988a,b). However the results could not be readily incorporated into stock assessment models. The main problem was that all the estimates of the asymptotic length $\left(L_{\infty}\right)$ were inferior to the maximum length observed from the samplings $\left(\mathrm{L}_{\mathrm{t}}=270 \mathrm{~mm}\right.$ ) except for the $\mathrm{L}_{\infty}$ estimated by Rijavec et al. (op cit.) which, on the contrary, was much superior.

The objectives of this study are: a) to verify the applicability of sardine length data to estimate growth parameters; b) to estimate growth parameters of the von Bertalanffy equation, the asymptotic length $\left(L_{\infty}\right)$, the growth rate $(K)$ and the age at zero length $\left(\mathrm{t}_{0}\right)$ for the
Brazilian sardine, during the period 1977-1987, applying several methods based on age and length data; and c) to estimate the natural and total mortality as well as the fishing mortality using the growth parameters.

\section{Material and methods}

Data from commercial landings of Sardinella brasiliensis were derived from the catches along the coasts of Rio de Janeiro, São Paulo and Santa Catarina States during the 1977-1992 period. The basic data used were as follows: weight in tons of the total landings per month for each state separately and monthly length frequency distributions from the materials collected at each state.

Catch data from the states of Rio de Janeiro and Santa Catarina were collected by IBAMA (Brazilian Institute for Environmental and Renewable Natural Resurces) based on boarding map system; in the state of São Paulo, the Marine Fishery Division of the Fishery Institute collected the data obtained by interviewing the fishermen.

The length frequency samples were raised to monthly catch for each state which were later summed up to account for the total length frequency distribution of the month for the entire area. For such, the raising factor (total catch weight/sample weight) and the weight/length relationship were used. These steps were executed with the aid of the "Compleat ELEFAN" program package (routine ELEFAN 0, Gayanilo et al., 1989).

The growth and mortality studies were carried out only for the 1977-1987 period when the Brazilian sardine stock has been in a relative equilibrium phase (Cergole, 1993).

The biological parameters considered here were extracted from literature references derived from the collections of the research programme "PIEBS" (Integrated Programme of Biological Studies on Sardine): a) the mean length at sexual maturity, $L_{4}=168 \mathrm{~mm}$; b) the weight/length relationships as follows: $\mathrm{W}_{\mathrm{t}}=\mathbf{0 . 0 0 0 0 0 1 8}$. $\mathrm{L}^{3.29}$ (expression considered for the 1977-1982 period), $\mathrm{W}_{\mathrm{t}}=0.0000023 \cdot \mathrm{L}_{\mathrm{t}}^{3.24}(1983), \mathrm{W}_{\mathrm{t}}=0.0000028 \cdot \mathrm{L}_{\mathrm{t}}^{3.21}$ $(1984), \mathrm{W}_{\mathrm{t}}=0.0000022 . \mathrm{L}^{3.26}(1985), \mathrm{W}_{\mathrm{t}}=0.0000016$. $\mathrm{L}_{\mathrm{t}}^{3.31}(1986) \mathrm{e} \mathrm{W}_{\mathrm{t}}=0.0000017 . \mathrm{L}^{3.30}(1987)$; and $\left.\mathrm{c}\right)$ the age/length keys. The mean length and weight of the captured specimens for the entire area, were estimated by each year; the mean individual weight per year were estimated for each length class.

\section{Growth parameters}

The growth parameters of the von Bertalanffy growth equation ( $\mathrm{L}_{\infty}$ and $\mathrm{K}$ ) were estimated annually and for the period $1977-1987$ as a whole, using length and age data. 


\section{Length frequency data}

The length frequency distribution data were analysed by means of the Compleat ELEFAN (Gayanillo et al.,op. cit).

The annual growth parameters for each state and for the entire area were estimated through the seasonalized von Bertalanffy growth equation (Pauly \& Gaschutz, 1979) by means of ELEFAN I method (ELEFAN I routine).

Bhattacharya's method (Bhattacharya, 1967) was also applied (using the MPA routine) for splitting the length frequency distribution of the entire area into separate normal distributions, according to age groups; afterwards, the growth parameters were estimated using the FISHPARM program (Saila et al., 1988).

The Wetherall method (Wetherall, 1986) modified by Pauly (1986) was used for estimating Lœ; ELEFAN II routine was used in the computations.

\section{Age data}

The mean length at age per year data were used in order to estimate the growth parameters by the Ford-Walford plot (Beverton \& Holt, 1957) and by means of the FISHPARM program(Saila et al., op. cit).

\section{Length and age data}

The same mean length at age data of the item $b$ above were also evaluated by means of the ELEFAN $V$ routine from the Compleat ELEFAN, which deals with the analysis of age and length frequency distribution at the same time.

Therefore, the mean growth parameters were calculated according to the values obtained in the different methods; the mean annual values were used for estimating the mortality rates.

The growth equation parameter to was estimated separately through Pauly's empirical formula, using the growth parameters obtained by the ELEFAN I method and also by the mean parameters resultant of all the methods employed.

\section{Mortality rates}

The instantaneous total, natural and fishing mortality coefficients were estimated, when possible, by several methods.

The instantaneous total mortality coefficient (Z) was estimated for each year of the 1977-1987 period and for the entire period by the catch curve method based on length at age data (Pauly, 1983, 1984b and 1984c) and also by means of two empirical formulas: Beverton \& Holt's (1956) equation and Ssentengo \& Larkin's (1973) equation based on the mean length of fish in the catches.

The catch curve was obtained by means of ELEFAN II from the Compleat ELEFAN, and $\mathbf{Z}$ was estimated from the descending part of the curve using length data and mean annual growth parameters.

The mean length for which $25 \%, 50 \%, 75 \%$ and $100 \%$ of the fish are under exploitation, were obtained by probability of catch curves using ELEFAN II. The $\mathrm{L}_{100 \%}$ value, or L', was used in the empirical formulas for calculating $\mathbf{Z}$.

The instantaneous natural mortality coefficient (M) was estimated by Pauly's (1980a) equation, which relates $M$ to the growth rate, $K$, annually, to the asymptotic, $L_{\infty}$, in centimeters, and to the water temperature, $\mathbf{T}$, in ${ }^{\circ} \mathrm{C} . \mathbf{M}$ was also estimated by Rikhter \& Efanov's (1976) formula, which relates $M$ to the length at sexual maturity, Lso.

Using the Pauly's formula (op. cit), M was estimated with the average values for $L_{\infty}$ and $K$ and the temperature $24^{\circ} \mathrm{C}$, through the ELEFAN II program. According to Pauly (1980a,b; 1984a), a correction factor of clupeoid fish 0.8 was used to obtain the $M$. The mean temperature value $\left(\mathrm{T}=24^{\circ} \mathrm{C}\right.$ ) was chosen based on Matsuura's (1983) consideration for the same area.

The value of $T_{50}$ introduced in Rikhter \& Efanov's formula correspondent to age at sexual maturity was obtained by the von Bertalanffy equation, using mean growth parameters for the whole period of study, the to obtained from the Pauly's empirical formula (Pauly, 1979), and length at sexual maturity.

The instantaneous fishing mortality coefficient $(F)$ was obtained by $\mathbf{F}=\mathbf{Z}-\mathbf{M}$, where the total $(\mathrm{Z})$ and natural (M) mortality coefficients used correspond to the mean values obtained for the period.

\section{Recruitment pattern}

The recruitment pattern was derived from the length frequency distribution by means of ELEFAN II, from the Compleat ELEFAN, using the mean growth parameters of ELEFAN I method and corresponding to.

\section{Results}

Since 1964, total sardine landings gradually increased reaching a maximum of 228 thousand tons in 1973. From the following year on, there was a reduction in yield exibiting two maximum points: between 1977 and 1980 with oscilations around 140 thousand tons and between 1983 and 1986, with oscilations around 125 thousand tons. After 1986 the catches decreased rapidly to about 32 thousand 
tons in 1990, being around 65 thousand tons in 1991 and 1992 (Fig. 2).

It can be noticed that after each period of reduction, the stock came to a new level of equilibrium, which was always inferior to the previous one.

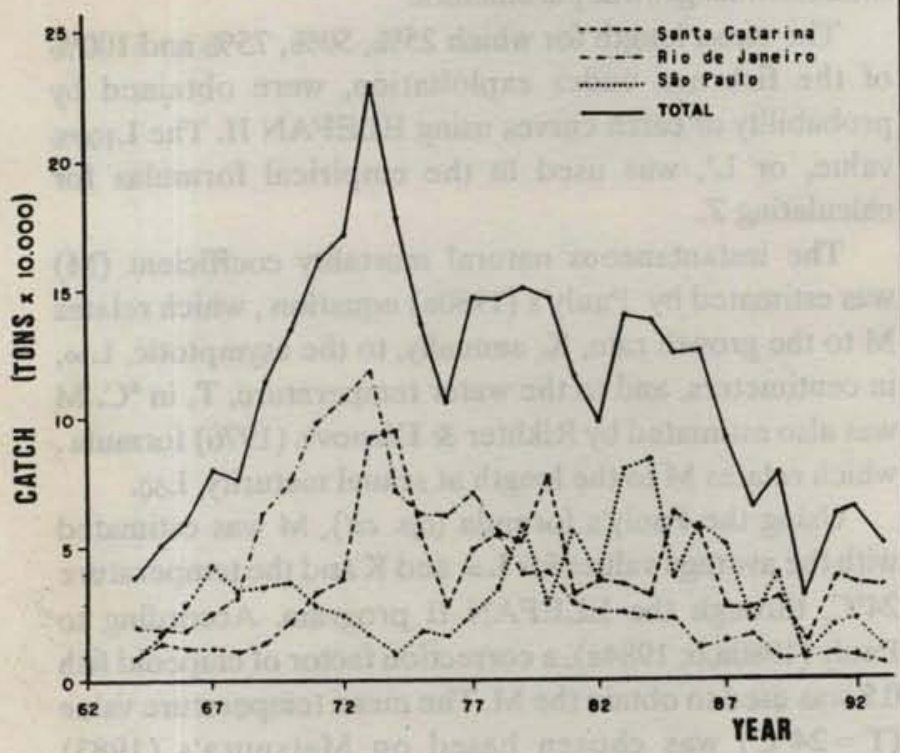

Fig. 2. Total catch of the Brazilian sardine, Sardinella brasiliensis, in each state and in the whole area.

\section{Length and weight composition}

The fish length in the commercial catches ranged from 90 to $270 \mathrm{~mm}$, most of them between the 150 and $220 \mathrm{~mm}$ total length. Large fishes from 260 and $270 \mathrm{~mm}$ classes were found during the years 1984 to 1986 . Length of recruitment can be considered $90 \mathrm{~mm}$ (Table 1).

The mean length of fish landed each year is presented in Table 1 and Figure 3. No abrupt variation in mean length is really noticed. The mean weight of the landed fish shows again no noticeable variation (Table 1 , Fig. 4).

\section{Growth parameters}

Length frequency data

Growth parameters obtained by ELEFAN I for each year, and state, and for the whole area and period are shown in Table 2.

The $\mathrm{C}$ values (range of growth oscilations) showed practically no variation, being equal to 0.6 except in 1987 when it reached 0.4 . The value obtained for $\mathrm{C}$ is acceptable for the surface water temperature range $\left(21^{\circ} \mathrm{C}\right.$ to $\left.27^{\circ} \mathrm{C}\right)$ observed in the Southeast region of Brazil (Matsuura, 1983, 1986b).

Table 1. Annual length frequency distribution $(x$ 1000) for the Brazilian sardine (Sardinella brasiliensis)

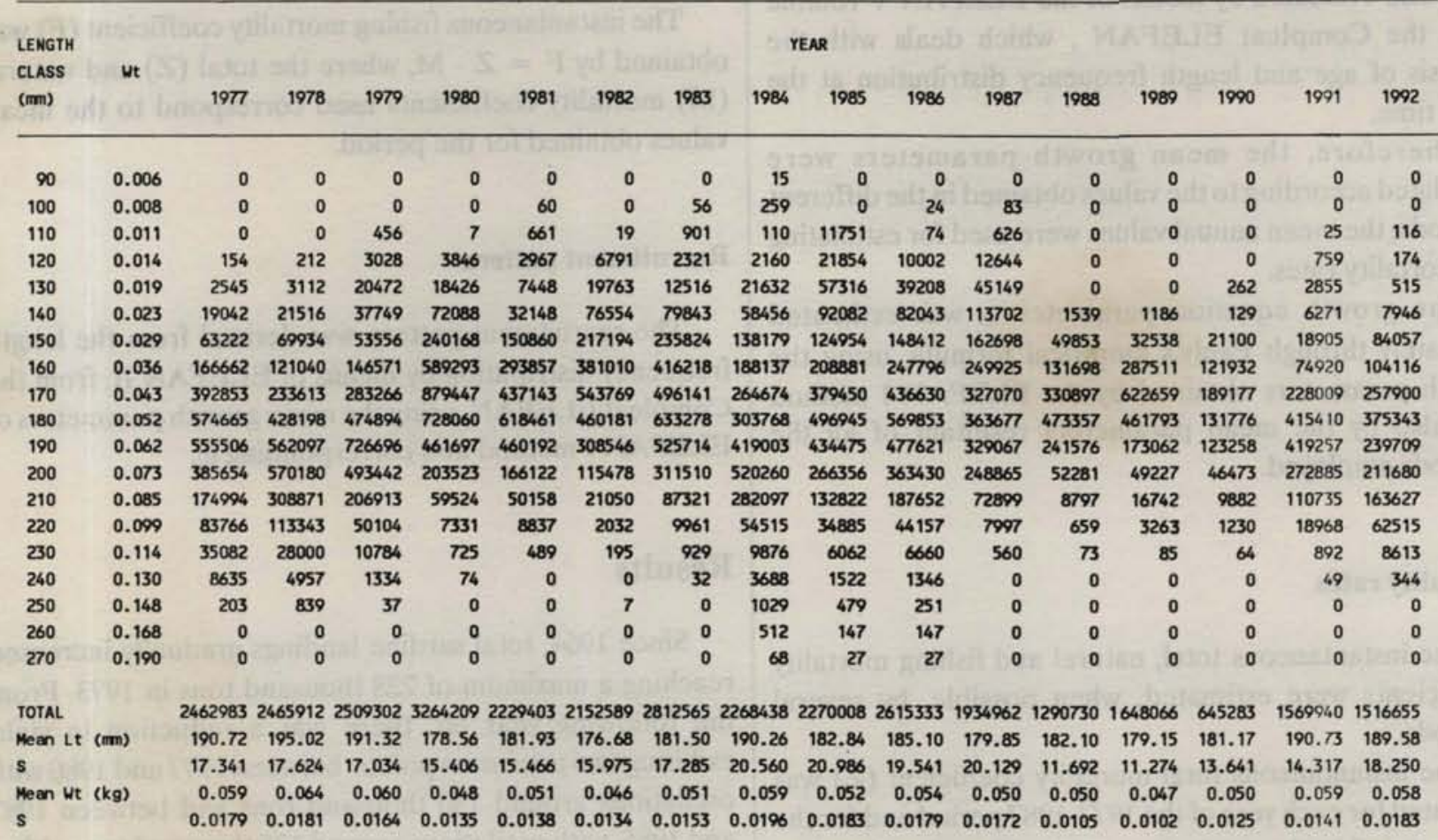




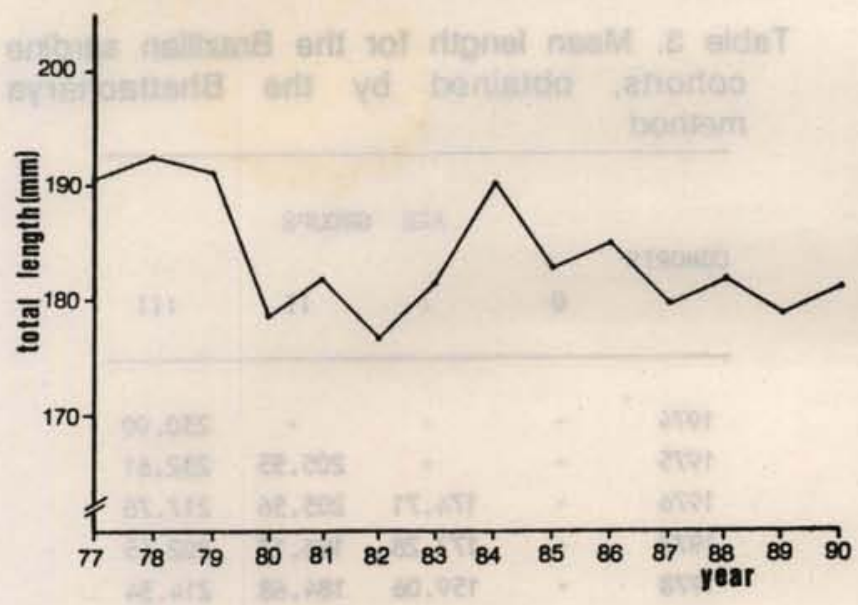

Fig. 3. Annual mean length $(\mathrm{mm})$ for the Brazilian sardine.

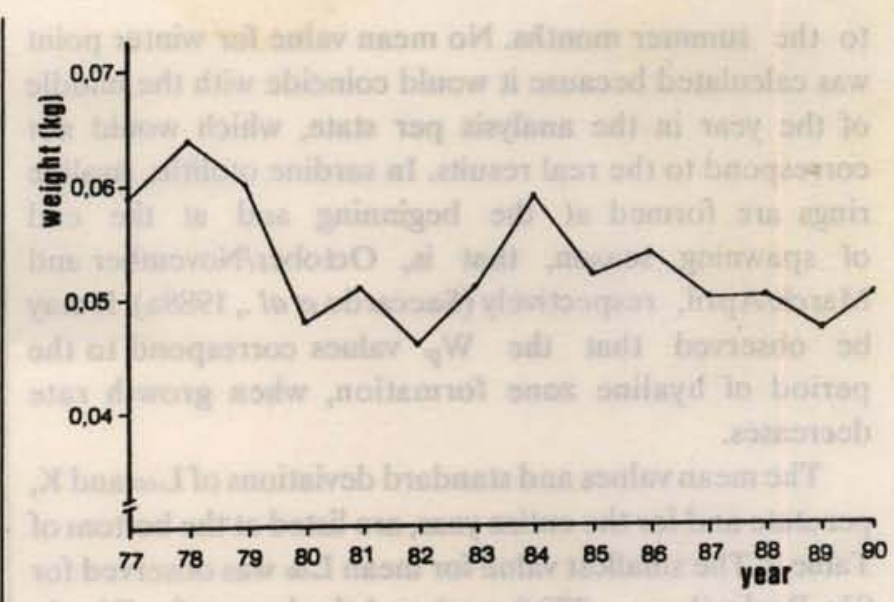

Fig. 4. Annual mean weight $(\mathrm{Kg})$ for the Brazilian sardine

Table 2. Annual growth parameters for the Brazilian sardine obtained by the ELEFAN I program

\begin{tabular}{|c|c|c|c|c|c|c|c|c|c|c|c|c|c|c|c|c|}
\hline \multirow[t]{2}{*}{ YEAR } & \multicolumn{4}{|c|}{ Säo Paulo } & \multicolumn{5}{|c|}{ Rio de Jane iro } & \multicolumn{3}{|c|}{ Senta Catar ina } & \multicolumn{4}{|c|}{ MHOLE MREA } \\
\hline & $L_{\infty}$ & k & c & UP & $L_{\infty}$ & K & c & w & $L \infty$ & K & c & $\mathbb{P}$ & $1 \infty$ & K & c & up \\
\hline 1977 & 275 & 0,73 & 0,60 & 0,00 & 276 & 0,70 & 0,60 & 0,03 & 288 & 0,69 & 0,60 & 0,00 & 278 & 0,69 & 0,60 & 0,10 \\
\hline 1978 & 278 & 0,67 & 0,60 & 0,30 & 276 & 0,70 & 0,60 & 0,30 & 285 & 0,67 & 0,60 & 0,30 & 280 & 0,68 & 0,60 & 0,30 \\
\hline 1979 & 284 & 0,65 & 0,61 & 0,45 & 276 & 0,68 & 0,60 & 0,40 & 280 & 0,69 & 0,60 & 0,40 & 288 & 0,72 & 0,60 & 0,30 \\
\hline 1980 & 288 & 0,70 & 0,60 & 0,40 & 291 & 0,74 & 0,60 & 0,80 & 282 & 0,70 & 0,60 & 0,40 & 280 & 0,68 & 0,60 & 0,50 \\
\hline 1981 & 272 & 0,62 & 0,60 & 0,90 & 282 & 0,69 & 0,60 & 0,90 & 276 & 0,65 & 0,60 & 0,10 & 279 & 0,69 & 0,60 & 0,10 \\
\hline 1982 & 271 & 0,59 & 0,60 & 0,95 & 288 & 0,71 & 0,60 & 0,10 & 272 & 0,64 & 0,60 & 0,90 & 280 & 0,69 & 0,60 & 0,00 \\
\hline 1983 & 269 & 0,65 & 0,60 & 0,40 & 285 & 0,71 & 0,60 & 0,30 & 270 & 0,65 & 0,60 & 0,50 & 276 & 0,68 & 0,60 & 0,20 \\
\hline 1984 & 282 & 0,70 & 0,60 & 0,30 & 294 & 0,74 & 0,60 & 0,30 & 266 & 0,69 & 0,60 & 0,40 & 297 & 0,73 & 0,62 & 0,32 \\
\hline 1985 & 272 & 0,68 & 0,60 & 0,40 & 288 & 0,71 & 0,60 & 0,10 & 285 & 0,70 & 0,60 & 0,10 & 291 & 0,70 & 0,60 & 0,40 \\
\hline 1986 & 285 & 0,70 & 0,60 & 1,00 & 294 & 0,73 & 0,60 & 0,90 & 291 & 0,71 & 0,60 & 0,70 & 285 & 0,69 & 0,60 & 0,00 \\
\hline 1987 & 282 & 0,69 & 0,60 & 0,90 & 287 & 0,69 & 0,60 & 0,49 & 276 & 0,69 & 0,60 & 0,10 & 272 & 0,62 & 0,40 & 0,00 \\
\hline Nean values & 278,00 & 0,68 & 0,60 & - & 285,20 & 0,71 & 0,60 & - & 279,20 & 0,68 & 0,60 & - & 282,40 & 0,69 & 0,58 & - \\
\hline $\mathbf{s}$ & 6,542 & 0,042 & 0,002 & - & 6,868 & 0,020 & 0,000 & - & 7,897 & 0,024 & 0,000 & - & 7,229 & 0,028 & 0,061 & - \\
\hline
\end{tabular}

\footnotetext{
$L_{\infty}=$ asymptotic length $(\mathrm{mm})$

$K=$ growth rate $\left(\right.$ year ${ }^{-1}$ )

Wp = "winter point"

c = amplitude of the growth oscillations

$\mathbf{S}=$ stendard deviation
}

The winter point $\left(\mathrm{W}_{\mathrm{p}}\right)$, that is, the season of the year of minimum growth rate, exhibited a greater variation though most of the values were concentrated within spring-summer, mainly at the end of spring $\left(W_{p}=0.8\right.$ to $1.0)$ and at the end of summer $\left(W_{p}=0.2\right.$ to 0.3$)$. For the global area, the obtained values corresponded principally 
to the summer months. No mean value for winter point was calculated because it would coincide with the middle of the year in the analysis per state, which would not correspond to the real results. In sardine otoliths, hyaline rings are formed at the beginning and at the end of spawning season, that is, October/November and March/April, respectively (Saccardo et al ., 1988a). It may be observed that the $W_{p}$ values correspond to the period of hyaline zone formation, when growth rate decreases.

The mean values and standard deviations of $\mathrm{L}_{\infty}$ and $\mathrm{K}$, per state and for the entire year, are listed at the bottom of Table 2. The smallest value for mean $\mathrm{L}_{\infty}$ was observed for São Paulo $\left(\mathrm{L}_{\infty}=278.0 \mathrm{~mm}\right)$ and the largest for Rio de Janeiro $\left(\mathrm{L}_{\infty}=285.2\right)$. The mean values for the entire area were $\mathrm{L}_{\infty}=282.4 \mathrm{~mm}$ and $\mathrm{K}=0.69$ year $^{-1}$.

Figure 5 shows the growth curves obtained by ELEFAN I for 1977 considering the entire area, which were plotted over histograms of length frequency using the growth parameters that presented the best results. Four age groups, three of them complete cohorts, and one formed by a few months, can be observed indicating that the species reaches a life span of little more than 3 years. This result agrees with studies on age based on otolith readings by Saccardo et al. (1988a, b).

By Bhattacharya's method (Bhattacharya, 1967) four modal groups were also identified. The average length for each modal group and the monthly increments in length of the cohorts are shown in Table 3 and Figure 7 respectively. The growth parameters estimated through this method were: $\mathrm{L}_{\infty}=296.6 \mathrm{~mm}$ and $\mathrm{K}=0.46$ year $^{-1}$.

The annual $L_{\infty}$ values obtained by the Wetherall method (Wetherall, 1986) modified by Pauly (1986) were in Table 4; the average $L_{\infty}$ value was $271.7 \mathrm{~mm}$. The curves plotted for 1977 as an example is in Figure 6.
Table 3. Mean length for the Brazilian sardine cohorts, obtained by the Bhattacharya method

\begin{tabular}{|c|c|c|c|c|}
\hline \multirow{2}{*}{ COHORTS } & \multirow[b]{2}{*}{0} & \multirow[t]{2}{*}{ AGE } & GROUPS & \multirow[b]{2}{*}{ III } \\
\hline & & & II & \\
\hline 1974 & - & - & - & 230.90 \\
\hline 1975 & - & - & 205.55 & 232.61 \\
\hline 1976 & - & 174.71 & 205.56 & 217.76 \\
\hline 1977 & - & 177.28 & 196.17 & 202.65 \\
\hline 1978 & - & 159.06 & 184.68 & 214.34 \\
\hline 1979 & - & 166.52 & 191.30 & 209.73 \\
\hline 1980 & 164.72 & 172.80 & 190.03 & 216.97 \\
\hline 1981 & 161.76 & 169.86 & 199.08 & 235.70 \\
\hline 1982 & - & 169.99 & 203.84 & 226.98 \\
\hline 1983 & 126.26 & 180.68 & 197.17 & 230.69 \\
\hline 1984 & 156.77 & 175.59 & 209.84 & 220.00 \\
\hline 1985 & 144.69 & 180.24 & 204.46 & - \\
\hline 1986 & $\cdot$ & 195.95 & - & - \\
\hline
\end{tabular}

Age data

In relation to the growth parameters estimated by the average length at age, the values for the entire period were $\mathrm{L}_{\infty}=228.5 \mathrm{~mm}$ and $\mathrm{K}=0.53$ year $^{-1}$ (using the Ford-Walford plot) and $\mathrm{L}_{\infty}=272.5 \mathrm{~mm}$ and $\mathrm{K}=0.55$ year ${ }^{-1}$ (using FISHPARM program).

\section{Length and age data}

The results of the combined analysis of age and length data using ELEFAN V are listed in Table 4; the mean values for the period were $\mathrm{L}_{\infty}=274.3 \mathrm{~mm}$ and $\mathrm{K}=0.72$ year ${ }^{-1}$.

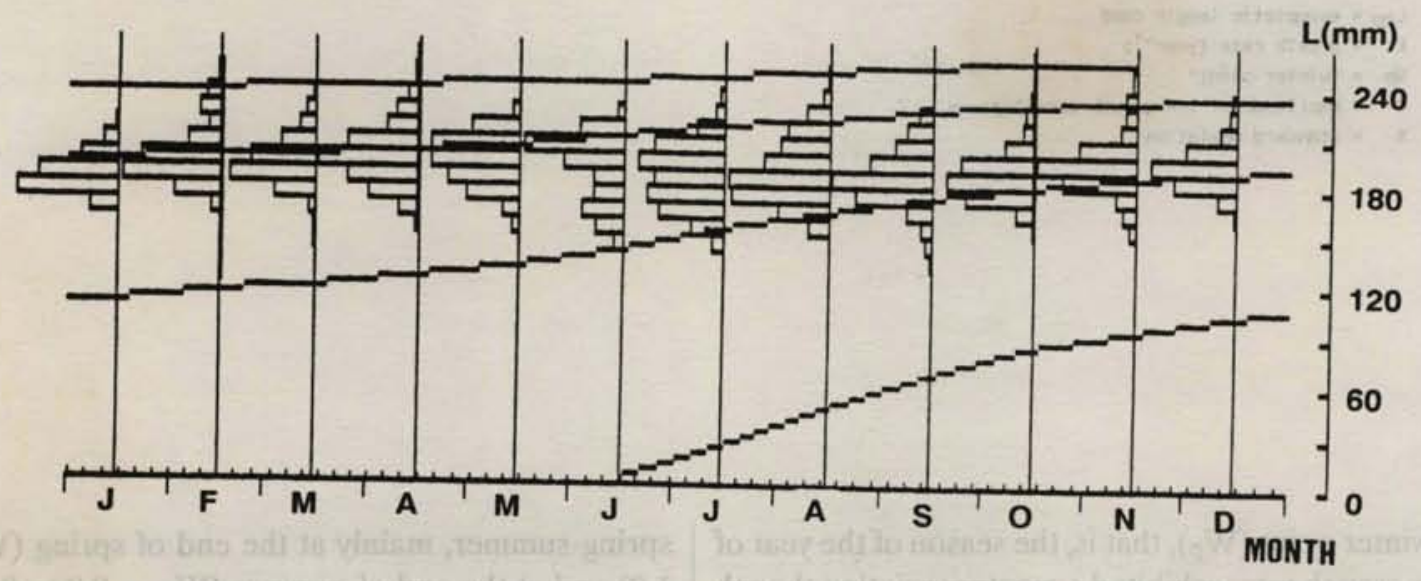

Fig. 5 - Growth curves of the Brazilian sardine based on ELEFAN I. Data from 1977 
Table 4. Annual growth parameters obtained for the 1977-1987 period, considering different methods, for the Brazilian sardine

\begin{tabular}{|c|c|c|c|c|c|c|c|c|c|}
\hline \multirow[t]{2}{*}{ YEAR } & \multicolumn{2}{|c|}{ ELEFAN I } & \multicolumn{2}{|c|}{ ELEFAN V } & \multicolumn{2}{|c|}{ (Ford-Waldord) } & \multirow{2}{*}{$\begin{array}{l}\text { WETHERALL } \\
L_{\infty}\end{array}$} & \multirow{2}{*}{$\begin{array}{l}\text { MEAN } \\
K\end{array}$} & \multirow{2}{*}{$\begin{array}{r}\text { VALUES } \\
\text { L }_{\infty}\end{array}$} \\
\hline & K & $L_{\infty}$ & K & $L_{\infty}$ & K & $L_{\infty}$ & & & \\
\hline 1977 & 0.60 & 278.0 & 0.78 & 240.0 & 0.56 & 234.0 & 272.6 & 0.68 & 256.2 \\
\hline 1978 & 0.68 & 280.0 & 0.76 & 292.0 & 0.62 & 229.0 & 290.3 & 0.69 & 272.8 \\
\hline 1979 & 0.72 & 288.0 & 0.70 & 280.0 & 0.63 & 222.0 & 271.6 & 0.68 & 265.4 \\
\hline 1980 & 0.68 & 280.0 & 0.70 & 290.0 & 0.32 & 246.0 & 268.6 & 0.57 & 271.2 \\
\hline 1981 & 0.69 & 279.0 & 0.71 & 294.0 & 0.43 & 225.0 & 261.9 & 0.61 & 265.0 \\
\hline enlline & 0.69 & 280.0 & 0.71 & 276.0 & 0.36 & 233.0 & $\cdot$ & 0.59 & 263.0 \\
\hline 1983 & 0.68 & 276.0 & 0.71 & 265.0 & 0.47 & 227.0 & 261.5 & 0.62 & 257.4 \\
\hline 1984 & 0.73 & 297.0 & 0.68 & 295.0 & 0.62 & 227.0 & 297.2 & 0.68 & 279.0 \\
\hline 1985 & 0.70 & 291.0 & 0.74 & 240.0 & 0.46 & 232.0 & 281.8 & 0.63 & 261.2 \\
\hline 1986 & 0.69 & 285.0 & 0.74 & 255.0 & 0.72 & 219.0 & 253.6 & 0.72 & 253.2 \\
\hline 1987 & 0.62 & 272.0 & 0.71 & 290.0 & 0.59 & 220.0 & 257.7 & 0.64 & 260.0 \\
\hline Mean values & 0.69 & 282.4 & 0.72 & 274.3 & 0.53 & 228.5 & 271.7 & & \\
\hline Standard deviation & 0.270 & 6.892 & 0.028 & 20.159 & 0.120 & 7.328 & 12.906 & & \\
\hline
\end{tabular}

$L_{\infty}=$ asymptot ic length $(\mathrm{nm})$
$K=$ growth rate $\left(\right.$ year $^{-1}$ )
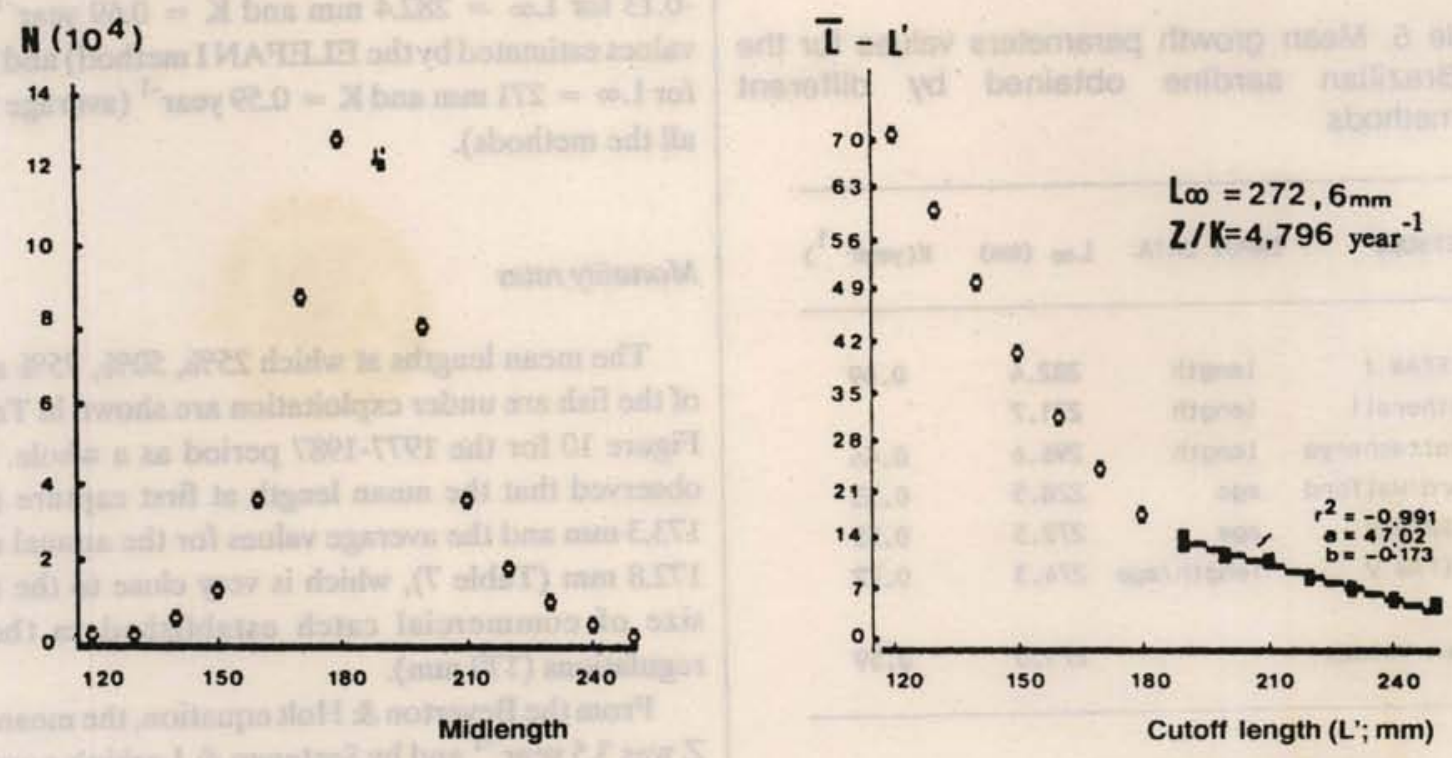

Fig. 6. Estimation of $\mathrm{L}_{\infty}$ value for the Brazilian sardine based on Wetherall method. Data from 1977. 


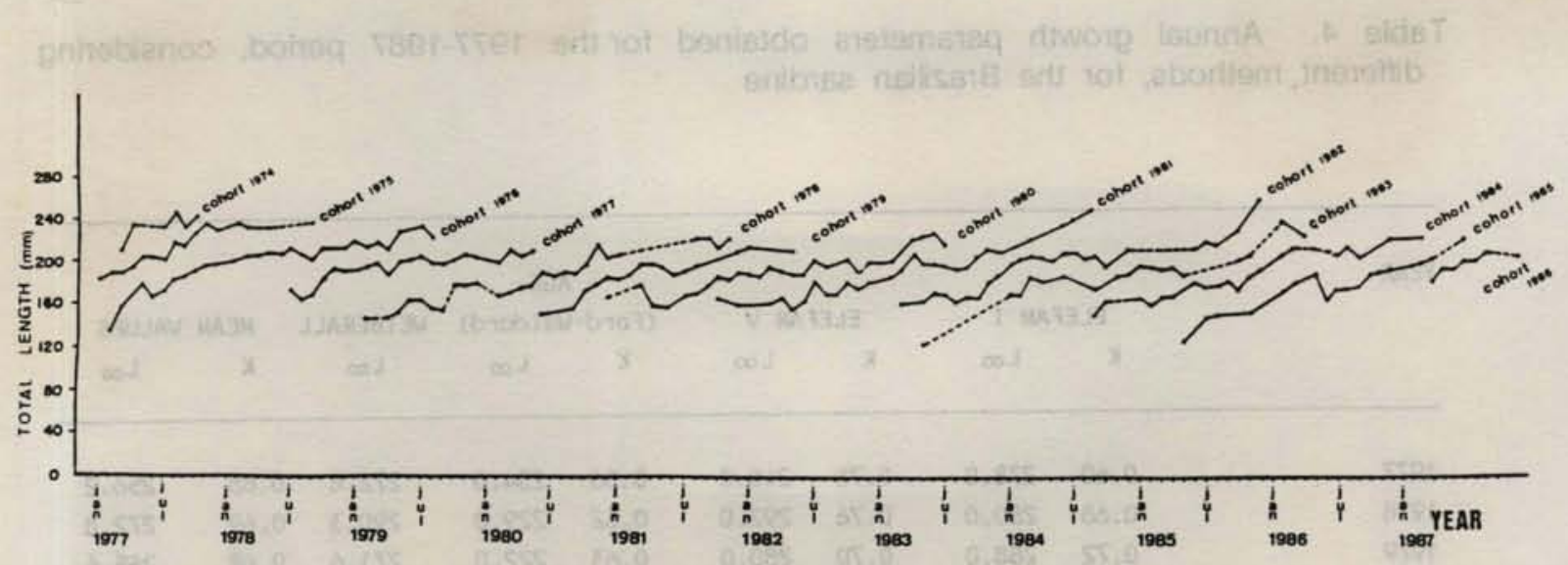

Fig. 7. Monthly length increments for the 1977-1987 Brazilian sardine cohorts, obtained with Bhattacharya method.

The growth parameters obtained annually by all the methods employed are listed in Table 4. When the results are compared based on the maximum length, some methods result in low values for $\mathrm{L}_{\infty}$ and high for $\mathrm{K}$, while others lead to opposite results, that is high $\mathrm{L}_{\infty}$ and low $\mathrm{K}$. For this reason, average values were estimated in order to counterbalance the effects of each method.

Table 5 shows the results obtained by several methods, considering the entire period under study. The average values were $L_{\infty}=271 \mathrm{~mm}$ and $K=0.59$ year $^{-1}$.

Table 6 and Figure 8 show the age composition and average length for each age class, based on the data of each semester. When the points are connected following the cohorts, it appears that there are two cohorts per year.

Table 5. Mean growth parameters values for the Brazilian sardine obtained by different methods

\begin{tabular}{|c|c|c|c|}
\hline METHODS & IMPUT DATA & $\mathrm{L}_{\infty}(\mathrm{mm})$ & $K\left(\right.$ year $\left.^{-1}\right)$ \\
\hline ELEFAN I & length & 282.4 & 0.69 \\
\hline Wetherall & length & 271.7 & \\
\hline Bhat tacharya & length & 296.6 & 0.46 \\
\hline Ford-Walford & age & 228.5 & 0.53 \\
\hline FISHPARM & age & 272.5 & 0.55 \\
\hline ELEFAN V & length/age & 274.3 & 0.72 \\
\hline Mean values & 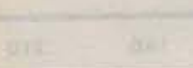 & 271.0 & 0.59 \\
\hline
\end{tabular}

$\mathrm{L}_{\infty}=$ asymptotic length $(\mathrm{mm})$

$K=$ growth rate $\left(\right.$ year $^{-1}$ )
The growth curves for the several year classes plotted per semester, using the average length values estimated by the mean annual parameters and corresponding to, obtained by Pauly's equation (Pauly, 1979), are shown in Figure 9. In order to plot the growth curve of the year-classes, a single cohort with birthday on $\mathbf{1}_{\mathrm{st}}$ January (such as those obtained by Bhattacharya's method and ELEFAN) was considered.

No significant variation in the mean growth rates was observed for the period under study, but a decrease in the mean lengths for $0.0 ; 0.5$ and 1.0 year-old classes, which can be interpreted as an increase in catch of younger fish, can be observed in Figure 8.

The values for the parameter to, age at zero length, estimated by Pauly's equation (Pauly, 1979), were: to = -0.13 for $\mathrm{L}_{\infty}=282.4 \mathrm{~mm}$ and $\mathrm{K}=0.69$ year $^{-1}$ (average values estimated by the ELEFAN I method) and to $=-0.15$ for $L \infty=271 \mathrm{~mm}$ and $K=0.59$ year $^{-1}$ (average values for all the methods).

\section{Mortality rates}

The mean lengths at which $25 \%, 50 \%, 75 \%$ and $100 \%$ of the fish are under exploitation are shown in Table 7 and Figure 10 for the $1977-1987$ period as a whole. It can be observed that the mean length at first capture ( $\left.\mathrm{L}_{50}\right)$ was $173.3 \mathrm{~mm}$ and the average values for the annual mean was $172.8 \mathrm{~mm}$ (Table 7), which is very close to the minimum size of commercial catch established in the fishing regulations $(170 \mathrm{~mm})$.

From the Beverton \& Holt equation, the mean value for $\mathrm{Z}$ was 3.5 year $^{-1}$ and by Ssetengo \& Larkin's equation, the mean value was 3.8 year $^{-1}$ (Table 8).

The $\mathrm{Z}$ values estimated by the annual catch curves (Table 8) ranged from 2.5 year $^{-1}$ (1977) to 5.2 year $^{-1}$ (1980), the calculated mean being 4.0 year $^{-1}$. As the sardine stock 
Table 6. Total catch (in number $\times 1000$ ) and mean length $(\mathrm{mm})$ for each age group for the Brazilian sardine

\begin{tabular}{|c|c|c|c|c|c|c|c|c|c|c|c|c|}
\hline \multirow{2}{*}{ AGE } & \multirow{2}{*}{\multicolumn{2}{|c|}{1977}} & \multirow{2}{*}{\multicolumn{2}{|c|}{1978}} & \multirow{2}{*}{\multicolumn{2}{|c|}{1979}} & \multirow{2}{*}{\multicolumn{2}{|c|}{$\begin{array}{ll}\text { YEAR } & \\
& 1980\end{array}$}} & \multirow{2}{*}{\multicolumn{2}{|c|}{1981}} & \multirow{2}{*}{\multicolumn{2}{|c|}{1982}} \\
\hline & & & & & & & & & & & & \\
\hline & & & & & & & & & & & & \\
\hline 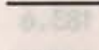 & 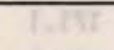 & 0.00 & & & 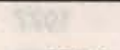 & & & & & & & \\
\hline 0.00 & 1128 & 141.93 & 0 & 137.39 & 3376 & 134.48 & 13478 & 137.83 & 4213 & 133.16 & 8738 & 135.42 \\
\hline 0.50 & 1833 & 156.85 & 2852 & 153.23 & 6038 & 140.18 & 3478 & 161.31 & 4215 & 151.93 & 7055 & 148.34 \\
\hline 1.00 & 402118 & 177.06 & 164566 & 188.71 & 354700 & 180.46 & 976780 & 168.48 & 424802 & 176.23 & 492432 & 168.86 \\
\hline 1.50 & 559070 & 178.95 & 599465 & 175.62 & 491212 & 175.16 & 1021383 & 175.55 & 744115 & 171.66 & 869070 & 170.57 \\
\hline 2.00 & 829722 & 197.17 & 977036 & 202.19 & 1059383 & 197.30 & 655215 & 187.64 & 711816 & 191.96 & 457199 & 189.64 \\
\hline 2.50 & 585457 & 198.87 & 600130 & 200.94 & 506812 & 200.02 & 566758 & 190.63 & 306476 & 190.16 & 300217 & 187.80 \\
\hline 3.00 & 65150 & 211.11 & 101541 & 209.93 & 79080 & 206.86 & 26277 & 205.70 & 32075 & 202.37 & 17411 & 201.57 \\
\hline 3.50 & 18502 & 231.08 & 20322 & 229.59 & 8699 & 226.29 & 839 & 219.71 & 1691 & 222.56 & 468 & 221.02 \\
\hline
\end{tabular}

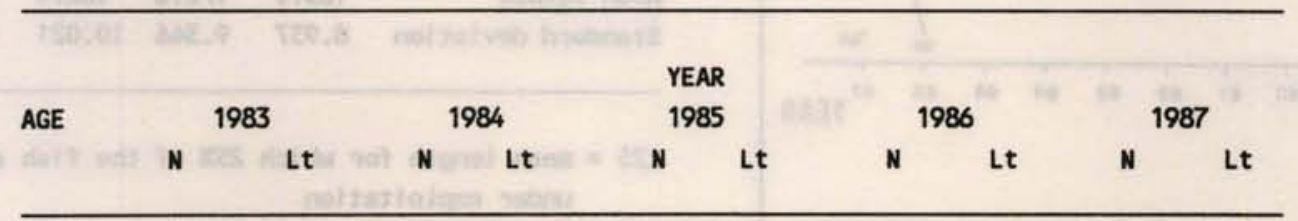

$\begin{array}{rrrrrrrrrrr}0.00 & 313 & 122.00 & 568 & 136.29 & - & - & 6 & 105.00 & 21 & 105.00 \\ 0.50 & 5809 & 138.35 & 820 & 121.55 & 846 & 130.40 & 23 & 128.91 & 407 & 124.65 \\ 1.00 & 294253 & 173.18 & 208697 & 181.60 & 186006 & 153.70 & 293338 & 155.47 & 316145 & 152.87 \\ 1.50 & 1208221 & 170.94 & 679130 & 170.64 & 773750 & 170.82 & 702224 & 175.44 & 585065 & 173.13 \\ 2.00 & 793925 & 194.51 & 670381 & 202.17 & 611004 & 191.70 & 867987 & 193.48 & 535453 & 190.43 \\ 2.50 & 487702 & 190.93 & 583035 & 198.22 & 551344 & 193.44 & 513391 & 190.52 & 385174 & 190.75 \\ 3.00 & 19126 & 205.39 & 101428 & 208.14 & 135006 & 205.31 & 233370 & 207.68 & 108346 & 202.69 \\ 3.50 & 3217 & 213.86 & 24377 & 222.68 & 12053 & 221.73 & 4994 & 216.25 & 4351 & 214.43\end{array}$

$N=$ number of $f$ ishes

$L t=$ mean total length $(\mathrm{mm})$

was under equilibrium during the period considered, it is convenient to use the combined data as a whole and plot a single catch curve, instead of estimating $Z$ year-to-year and calculate the mean. So, considering the data altogether for the entire period, the $Z$ was equal to 3.0 year $^{-1}$ (Fig. 11).

The average total mortality coefficient considered for the 1977-1987 period as a whole was the mean calculated for the 4 values above, that is, $Z=3.6$ year $^{-1}$.

The instantaneous natural mortality coefficients obtained from Pauly's equation (Pauly, 1980a) was $\mathrm{M}=$ 0.96 year $^{-1}$ using the mean values of the growth parameters $\left(\mathrm{L}_{\infty}=271 \mathrm{~mm}\right.$ and $\left.\mathrm{K}=0.59 \mathrm{year}^{-1}\right)$ and $\mathrm{T}=24^{\circ} \mathrm{C}$.

The estimation of the natural mortality obtained by Rikhter \& Efanov's equation (1976) was 0.98 year $^{-1}$, considering the first maturation as 1.5 years. This value is very similar to the previous result obtained by Pauly's empirical formula.

The fishing mortality coefficient was estimated as 2.6 year ${ }^{-1}$ by the difference between the values of total $(\mathrm{Z}=$ 3.6 year $\left.^{-1}\right)$ and natural $\left(M=0.96\right.$ year $\left.^{-1}\right)$ mortality coefficients.

\section{Recruitment pattern}

The greatest percentage of recruitment occurred in the month of July (17.38\%). This agrees with the observed field exploitation of the young fish, that is more intensively during the winter months of June to August. 


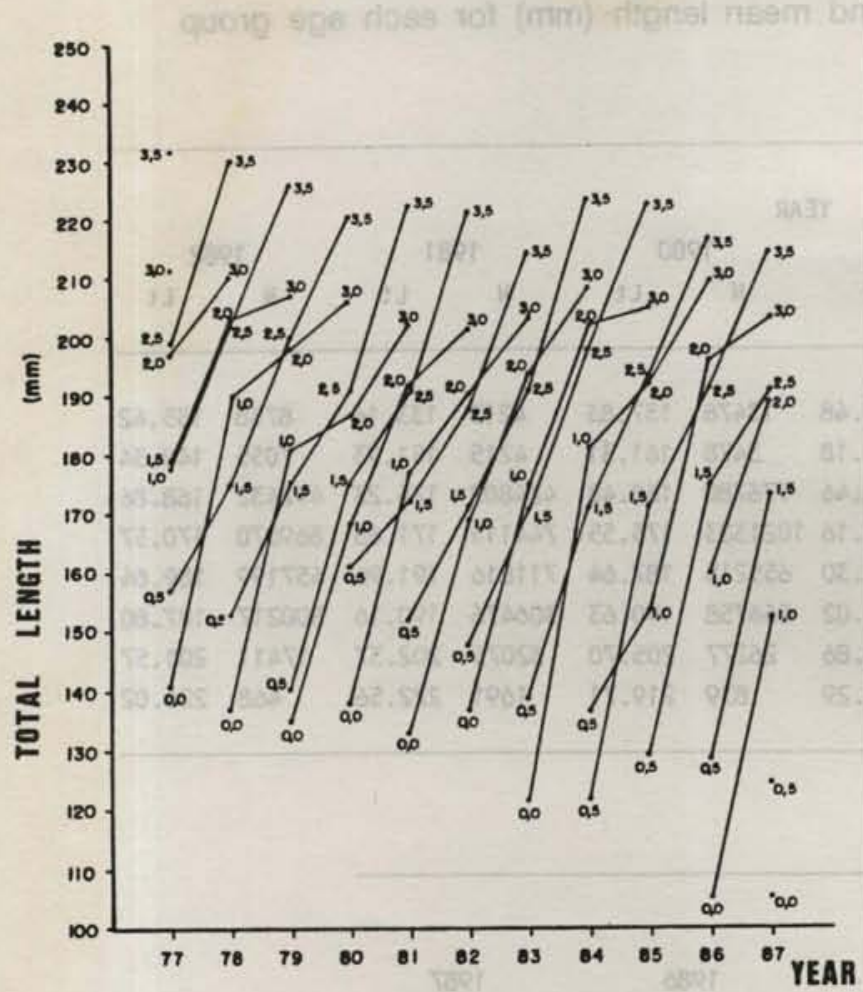

Fig. 8. Mean annual length at age for the Brazilian sardine.

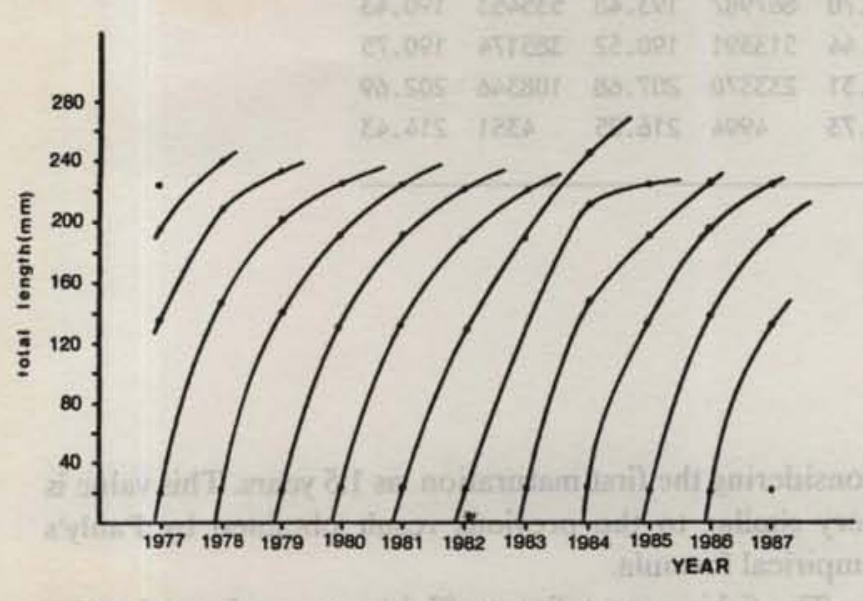

Fig. 9. Annual growth curves for the Brazilian sardine.

\section{Discussion}

After 1985, there has been an increase in fishing effort over the sardine stock due to the use of new modern boats, and also to an intensive exploitation of juveniles by fishermen (IBAMA, 1991a, b;1992). It is possible that these changes in the fishing vessels, with a consequent
Table 7. Mean length values obtained by catch probability curve for the Brazilian sardine

\begin{tabular}{|c|c|c|c|c|c|c|}
\hline YEAR & \multicolumn{2}{|c|}{ हाला } & $\begin{array}{r}\mathrm{L} 25 \\
(\mathrm{~mm})\end{array}$ & $\begin{array}{r}150 \\
(\mathrm{~mm})\end{array}$ & $\begin{array}{r}L 75 \\
\text { (mm) }\end{array}$ & $\begin{array}{l}\mathrm{L} 100 \\
(\mathrm{~mm})\end{array}$ \\
\hline \multicolumn{3}{|l|}{1977} & 170.6 & 171.1 & 183.6 & 190.0 \\
\hline \multicolumn{3}{|l|}{1978} & 185.5 & 193.5 & 201.6 & 200.0 \\
\hline \multicolumn{3}{|l|}{1979} & 185.2 & 194.0 & 202.9 & 200.0 \\
\hline \multirow{2}{*}{$\begin{array}{l}1980 \\
1981\end{array}$} & ks wat & wetst & 168.0 & 173.1 & 178.1 & 180.0 \\
\hline & sed.cy & 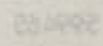 & 175.2 & 182.0 & 188.9 & 190.0 \\
\hline 1982 & etsish & sturche & 155.2 & 160.3 & 165.5 & 180.0 \\
\hline 1983 & 20 atos & 05008 & 178.4 & 185.3 & 192.1 & 190.0 \\
\hline 1984 & ee. wes & Tatrot & 165.0 & 172.9 & 180.7 & 210.0 \\
\hline \multicolumn{3}{|l|}{$\begin{array}{l}1985 \\
1986\end{array}$} & 161.6 & 172.7 & 183.7 & 190.0 \\
\hline 1986 & & & 173.6 & 180.9 & 188.2 & 190.0 \\
\hline \multicolumn{3}{|l|}{1987} & 168.3 & 176.1 & 183.9 & 180.0 \\
\hline \multicolumn{3}{|c|}{ Mean values } & 163.0 & 172.8 & 182.4 & 190.0 \\
\hline \multicolumn{3}{|c|}{ Standard deviation } & 8.937 & 9.346 & 10.021 & 9.000 \\
\hline
\end{tabular}

L25 = mean length for which $25 \%$ of the fish are under exploitation

$\mathbf{L S O}=$ mean length for which $\mathbf{5 0 \%}$ of the $\mathrm{fish}$ are under exploitation

$\mathbf{L} 75=$ mean length for which $75 \%$ of the fish are under exploitation

$L 100=L^{\prime}=$ mean length for which $100 \%$ of the fish are under exploitation

$125=163,6 \mathrm{~mm}$ L5O $=173,3 \mathrm{~mm}$ $175=182,9 \mathrm{~mm}$

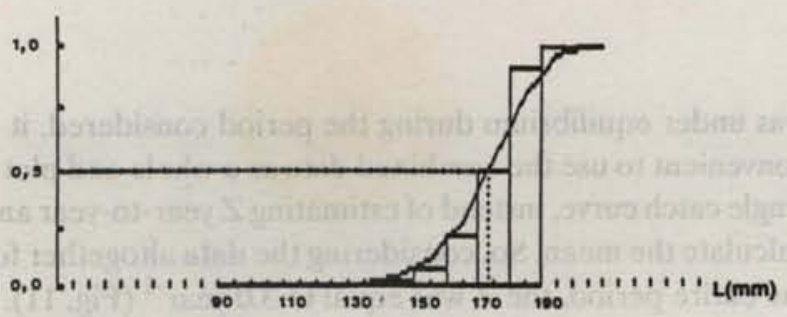

Fig. 10. Catch probability curve for the Brazilian sardine.

increase in the fishing power, had contributed with the reduction of the sardine stock. Apparently it did not reflect in the density-dependent parameters. Only a decrease in the mean length of the young fish ( 0.5 year) was observed during the period. 
Table 8. Annual total mortality coefficients for the Brazilian sardine obtained by different methods

TOTAL MORTALITY

\begin{tabular}{|c|c|c|c|}
\hline$x^{2}$ & $\begin{array}{l}\text { Beverton } \\
\& \text { Holt } \\
(1956)\end{array}$ & $\begin{array}{l}\text { Ssentengo } \\
\& \text { Lark in } \\
\text { (1973) }\end{array}$ & $\begin{array}{l}\text { Catch } \\
\text { curve }\end{array}$ \\
\hline 1977 & 2.468 & 2.794 & 2.504 \\
\hline 1978 & 3.716 & 4.052 & 4.266 \\
\hline 1979 & 3.952 & 4.284 & 4.585 \\
\hline abis alk a & 3.656 & 3.934 & 5.187 \\
\hline mationsta & 4.257 & 4.555 & 4.884 \\
\hline 1982 & 3.632 & 3.919 & 3.602 \\
\hline 1983 & 3.322 & 3.623 & 4.776 \\
\hline 1984 & 5.414 & 5.747 & 3.431 \\
\hline 1985 & 2.902 & 3.207 & 2.751 \\
\hline 1986 & 2.701 & 3.047 & 3.567 \\
\hline 1987 & 2.751 & 3.060 & 3.954 \\
\hline Mean values & 3.525 & 3.838 & 3.955 \\
\hline Standard deviation & 0.808 & 0.808 & 0.834 \\
\hline
\end{tabular}

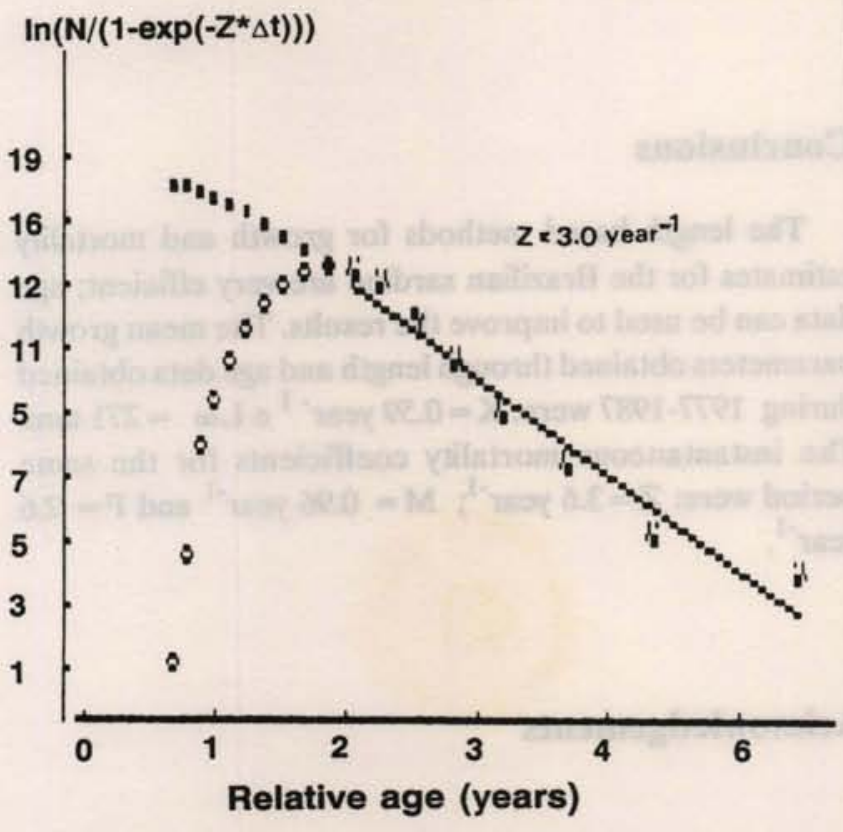

Fig. 11. Length converted catch curve for the Brazilian sardine. Data from 1977-1987 period.

Considering only the analysis of the variations of the density- dependent parameters (mean length and weight, and growth rate), for the period under study, they showed no signs of a future fishing collapse of $S$. brasiliensis.
In the previous studies concerning age and growth of the Brazilian sardine, growth parameters were estimated using length and age data obtained from countings of growth rings in otoliths and scales. The results were not satisfactory because the asymptotic length estimated was smaller than lengths obtained in the commercial fishery.

In the present study, with the use of microcomputer and softwares in the analysis of length frequency distributions and non- linearized adjustments in analysis of age data, the estimated average growth parameters $\left(\mathrm{L}_{\infty}=271 \mathrm{~mm}\right.$ and $\mathrm{K}=0.59$ year $^{-1}$ ) were satisfactory. Also, the methods (ELEFAN I, Bhattacharya, Wetherall and ELEFAN V) based on length frequency data were very efficient on the estimate of the parameters because they were applied to the species on a balanced equilibrium of the stock, where the annual variations on the recruitment were small. In addition, the availability of the age data was important to improve the estimate of the parameters.

When Saccardo et al. (1988a, b) analyzed the growth of the Brazilian sardine, they considered two groups per year: one composed by the fish that were born in the beginning of spawning season and the other in the end of it. By application of Bhattacharya's method to the length frequency distribution it became evident that a single cohort is formed each year, which agrees with the growth curves obtained by the ELEFAN I method. Although the spawning season is long (from October to March), the intensive spawning takes place within a relative short period, generally in December-January (Matsuura, 1977, 1988).

For stock assessment purposes only one cohort with the birthday date of January $1^{\text {st }}$ can be considered (Cergole, 1993).

The growth performance index, Phi prime $\phi$ ' (Munro \& Pauly, 1983; Pauly \& Munro, 1984), was used for comparison of the several estimates of the growth parameters presented in literature and our results. Table 9 shows the values for $L_{\infty}$ and $K$ and correspondent $\phi^{\prime}$. The highest value calculated was $\phi^{\prime}=4.99$, for the growth parameters estimated by Rijavec et al. (1977) (in the $23^{\circ}-25^{\circ} \mathrm{S}$ area) and the lowest $\phi^{\prime}=4.13$, for parameters obtained by Vazzoler et al. (1987), for the area between $25^{\circ}$ and $26^{\circ}$ S (Cananéia, SP - Paranaguá, PR). The former authors estimated the growth rate $(K=0.87)$ and the asymptotic length $\left(\mathrm{L}_{\infty}=335 \mathrm{~mm}\right)$, using the modal progression method of length frequency distributions, resulting a very large value for $L_{\infty}$. On the other hand, Vazzoler et al. (op. cit) estimated the growth parameters $\left(\mathrm{L}_{\infty}=115.16 \mathrm{~mm}\right.$ and $\mathrm{K}=1.02$ year $\left.^{-1}\right)$ using the Ford-Walford plot applied to the mean length at age data obtained by otolith readings; in this case, the estimation was made based on samples of young fish, which could have influenced the calculations, resulting in an underestimate asymptotic length. 
Table 9. Growth Performance Index $\left(\phi^{\prime}\right)$ values for the Brazilian sardine, for different sets parameters

\section{AUTHORS}

$$
\text { AREA } \underset{(\mathrm{mm})}{\mathrm{L}_{\infty}} \mathrm{K}\left(\text { year }^{-1}\right) \phi^{\prime}
$$

\begin{tabular}{|c|c|c|c|c|}
\hline Richardson et al., 1960 & $22-23 \cdot s$ & 254.20 & 0.31 & 4.30 \\
\hline Santos \& Fratzen, 1965 & $22-23^{\circ} \mathrm{s}$ & 243.00 & 0.50 & 4.47 \\
\hline Matsura, 1977 & $22-23^{\circ} \mathrm{s}$ & 244.00 & 0.44 & 4.42 \\
\hline Ri javec et al.., 1977 & $23-25^{\circ} \mathrm{s}$ & 335.00 & 0.87 & 4.99 \\
\hline Matsura, 1983 & $22-28^{\circ} \mathrm{s}$ & 260.00 & 0.62 & 4.62 \\
\hline Vazzoler et al., 1987 & $22-23^{\circ} s$ & 232.94 & 0.62 & 4.53 \\
\hline Vazzoler et al.,, 1987 & $23-25^{\circ} \mathrm{s}$ & 229.86 & 0.37 & 4.29 \\
\hline Vazzoler et al., 1987 & $25-26^{\circ} \mathrm{s}$ & 115.16 & 1.02 & 4.13 \\
\hline Saccardo et al., 1988a & $22-28^{\circ} \mathrm{s}$ & 230.99 & 0.72 & 4.58 \\
\hline Saccardo et al., 1988a & $22-28^{\circ} \mathrm{s}$ & 226.09 & 0.72 & 4.56 \\
\hline Cergole (average values)* & $22-28^{\circ} \mathrm{s}$ & 271.00 & 0.59 & 4.64 \\
\hline Cergole (ELEFAN I)* & $22-28^{\circ} \mathrm{s}$ & 282.40 & 0.69 & 4.74 \\
\hline
\end{tabular}

$\mathrm{L}_{\infty}=$ asymptotic length $(\mathrm{mm})$

$K=$ growth rate year $^{-1}$ )

* = results of this work

The values of $\phi^{\prime}$ for the growth parameters estimated by the various authors did not demonstrate significant variation except for those mentioned and discussed above, which are considered extreme values.

Once the growth parameters were known, it was possible to estimate the instantaneous total $\left(\mathrm{Z}=3.6\right.$ year $\left.^{-1}\right)$ and natural $\left(\mathrm{M}=0.96\right.$ year $\left.^{-1}\right)$ mortality coefficients.

The best estimates for $\mathrm{Z}$ using the catch curve method for the sardine stock was those based on pooled data (from 1977 to 1987). In this manner, annual variations in recruitment were eliminated, simulating a true equilibrium situation.

The methods for estimating natural mortality in fish population include the analysis of data from commercial catch or from sampling programs specific for stock assessment. The $M$ values can be estimated by catch per unit fishing effort data, by correlation with other parameters of the life cycle and by predation studies (Vetter, 1988).

Since there were some problems with the data on catch per unit of effort (CPUE) and no data of predation was available for the Brazilian sardine, it was only possible to apply the empirical methods. The results, when comparing the one derived from the use of Pauly's equation (Pauly, 1980) raised for clupeoids with the one derived from Rikhter \& Efanov's equation, were very similar. This provided reliabity to the results, since they are based on different criteria.

Beverton (1963) estimated M/K for 13 species of engraulidids and clupeids including the genus Sardinella, and the values ranged between 1.0 and 2.0. In the present study the values of $\mathrm{M} / \mathrm{K}$ estimated for the Brazilian sardine $(\mathrm{M} / \mathrm{K}=1.63)$ occur within the range observed by the author cited above.

The fishing mortality rate gives an idea of the exploitation rate $(E=F / Z)$ of the Brazilian sardine, which is 0.72 year $^{-1}$. This value can lead to the conclusion that the sardine stock is being intensively exploited. It is considered here that this may be the main cause of the stock reduction.

The fishing mortality rates per age, per year, was calculated through Virtual Populations Analysis (Cergole, 1993). An increase of the mortality rates after 1985 was observed; this variation can be correlated with an increase in the fleet size and in the fishing power.

\section{Conclusions}

The length based methods for growth and mortality estimates for the Brazilian sardine are very efficient; age data can be used to improve the results. The mean growth parameters obtained through length and age data obtained during 1977-1987 were: $\mathrm{K}=0.59$ year $^{-1} \mathrm{e} \mathrm{L \infty}=271 \mathrm{~mm}$. The instantaneous mortality coefficients for the same period were: $\mathrm{Z}=3.6$ year $^{-1} ; \mathrm{M}=0.96$ year $^{-1}$ and $\mathrm{F}=2.6$ year ${ }^{-1}$.

\section{Acknowledgements}

We thank all scientists from the Integrated Programme of Biological Studies on Sardine (PIEBS), with special reference to M. Teixeira-Wenzel and R. de D. Cardoso for their help in obtaining sardine fishing data.

We also thank Dr C. L. D. B. Rossi-Wongtschowski for advisory of this work, Dr Jorge Pablo Castello for suggestions and Dr S. A. Saccardo for revision of the manuscripts. 


\section{References}

BAKUN, A. \& PARRISH, R. H. 1990. Comparative studies of coastal pelagic fish reproductive habitats: the Brazilian sardine (Sardinella aurita). J. Cons. int. Explor. Mer, 46:269-283.

BHATTACHARYA, C. G. 1967. A simple method of resolution of a distribution into Gaussian components. Biometrics, 23:115-135.

BEVERTON, R. J. H. 1963. Maturation, growth and mortality of clupeid and engraulid stocks in relation to fishing. Rapp. P.-v. Réun. Cons. perm. int. Explor. Mer, 154:47-67.

BEVERTON, R. J. H \& HOLT, S. J. 1956. A review of methods for estimating mortality rates in exploited fish populations, with special reference to sources of bias in catch sampling. Rapp. P.-v. Réun. Cons. perm. int. Explor. Mer, 140:67-83.

BEVERTON, R. J. H. \& HOLT, S. J. 1957. On the dynamics of exploited fish populatios. Fishery Invest., Ser. II, Lond., 19, 533p.

CERGOLE, M. C. 1993. Avaliação do estoque da sardinha- verdadeira, Sardinella brasiliensis, da costa sudeste do Brasil, período 1977-1990. Tese de doutorado. Universidade de São Paulo, Instituto Oceanográfico. 245p.

EKAU, W. \& MATSUURA, Y. 1991. Impact of starvation of clupeiform fish larvae on the variability of recruitment. In: Ekau, W., ed. 1991. Brazilian German Victor Hensen Programme, Joint Oceanographic Projects, JOPS '90/91, Cruise Report:31-39.

GAYANILO Jr, F. C.; SORIANO, M. \& PAULY, D. 1989. A draft guide to the Compleat ELEFAN. ICLARM Software 2, 70. ICLARM Contr., (435): 71p.

IBAMA. 1991a. Relatório da reunião técnica do Grupo Permanente de Estudos sobre Sardinha. Itajaí, IBAMA/CEPSUL. 31p.

1991b. Relatório da reunião do Grupo Permanente de Estudos sobre Sardinha. Itajaí, IBAMA/CEPSUL. 16p.

1992. Relatório da reunião técnica sobre Sardinha. Itajaí, IBAMA/CEPSUL. 8p.

LIN, C. F. 1992. Atuns e afins: estimativa da quantidade de isca-viva utilizada pela frota atuneira. IBAMA, Coleçāo Meio Ambiente. Série Estudos-Pesca, 6:80p.
MATSUURA, Y. 1977. O ciclo de vida da sardinha-verdadeira (introdução à oceanografia pesqueira). Publçāo esp., Inst. oceanogr., S Paulo, (4):1-146.

1983. Estudo comparativo das fases iniciais do ciclo de vida da sardinha-verdadeira, Sardinella brasiliensis e da sardinha-cascuda, Harengula jaguana, (Pisces: Clupeidae) e nota sobre a dinâmica da população da sardinha-verdadeira na regiāo sudeste do Brasil. Tese de livre-docência. Universidade de Sāo Paulo, Instituto Oceanográfico. 150p.

1986. Contribuição ao estudo da estrutura oceanográfica entre Cabo Frio (RJ) e Cabo de Santa Marta Grande (SC). Ciência Cult., S Paulo, 38(8):1439-1450.

1988. Synopsis on the reproductive and early life history of the Brazilian sardine, Sardinella brasiliensis and related environmental conditions. IOC Workshop Report (65), annex VIII. 8p.

1990. Rational utilization of coastal ecosystem in tropics: integrated investigation of coastal ecosystem in Ubatuba region. In: SIMPÓSIO DE ECOSSISTEMAS DA COSTA SUL E SUDESTE BRASILEIRA: ESTRUTURA FUNÇĀO E MANEJO, 2., Águas de Lindóia, 1990. São Paulo, Academia de Ciências do Estado de São Paulo.v.1, p.47-52.

;SPACH, H.L. \& KATSURAGAWA, M. 1992 Comparison of spawning patterns of the Brazilian sardine (Sardinella brasiliensis) and anchoita (Engraulis anchoita) in Ubatuba region, southern Brazil during 1985 trough 1988. Bolm Inst. oceanogr., S Paulo, 40(1/2):101-115.

MESNIL, B. 1988. Computer programs for fish stock assessment. ANACO: Software for the analysis of catch data by age group on IBM PC and compatibles. FAO Fish. tech. Pap., (101, suppl. 3): 1-73.

MUNRO, J. L. \& PAULY, D. 1983. A simple method for comparing the growth of fishes and invertebrates. Fishbyte, 1(1):5-6.

PAULY, D. 1979. Gill size and temperature governing factors in fish growth: a generalization of von Bertalanffy's growth formula. Ber. Inst. Meeresk. Univ. Kiel, (63): xv + 156p.

1980a. On the interrelationships between natural mortality, growth parameters, and mean environmental temperature in $\mathbf{1 7 5}$ fish stocks. J. Cons. int. Expl. Mer, 39(2):175-192. 
PAULY, D. 1980b. A selection of simple methods for the assessment of tropical fish stocks. FAO Fish. Circ., (729):1-53.

1983. Length-converted catch curves: a powerful tool for fisheries research in the tropics (Part I). Fishbyte, 1(2):9-13.

1984a. Fish population dynamics in tropical waters: a manual for use with programmable calculators. ICLARM Stud. Rev., (8):325p.

1984b. Length-converted catch curves: a powerful tool for fisheries research in the tropics (Part II). Fishbyte, 2(1):17-21.

1984c. Length-converted catch curves: a powerful tool for fisheries research in the tropics (III: conclusion). Fishbyte, 2(3):9-10.

1986. On improving operation and use of the ELEFAN programs. Part II. Improving the estimation of L $\infty$. Fishbyte, 4(1):18-20.

\& GASCHUTZ, G. 1979. A simple method for fitting oscillating length growth data, with a program for pocket calculators. ICES C.M. 1979/G, 24. 26p. (mimeo).

\& MUNRO, J. L. 1984. Once more on the comparison of growth in fish and invertebrates. Fishbyte, 2(1):p.21.

RICHARDSON, I. D.; VAZZOLER, G.; FARIA, A. de \& MORAES, M. N. de. 1960 . Report on sardine investigations in Brazil. In: Proceedings of the World Scientific Meeting on the Biology of Sardines and Related Species. FAO. Proc. Sardine Meeting, 3(13):1051-1079.

RIJAVEC, L.; JABLONSKI, S.; SIMON, A. S. C. B.; RODRIGUES, L. F. \& PIRES, M. R. Q. 1977. Contribuiçāo ao conhecimento da biologia e dinâmica da sardinha (Sardinella brasiliensis) em águas brasileiras (resultados preliminares). Sér. Doc. Oc. SUDEPE/PDP, 24:1-36.

RIKHTER, V. A. \& EFANOV, V.N. 1976. On one of the approaches to estimation of natural mortality of fish populations. ICNAF Res. Doc., $76(\mathrm{VI}, 8)$ : 12p.

ROSSI-WONGTSCHOWSKI, C. L. D. B. \& SACCARDO, S. A., coord. 1991. Distribuição e abundância da sardinha e da anchoita na regiāo sudeste do Brasil: outubro - novembro, 1988. Publçāo esp. Inst. oceanogr., S Paulo, (8):50p.
ROSSI-WONGTSCHOWSKI, C. L. D. B.; VAZZOLER, A. E. A. de M. \& BRAGA, F. M. de S. 1982. Estudos sobre estrutura, ciclo de vida e comportamento de Sardinella brasiliensis (Steindachner, 1879), na área entre $22^{\circ} \mathrm{S}$ e $28^{\circ} \mathrm{S}$, Brasil. I. Morfologia dos otólitos. Bolm Inst. oceanogr., S Paulo, 31(2):57-76.

SACCARDO, S. A. \& ROSSI-WONGTSCHOWSKI, C.L.D.B. 1991. Biologia e avaliaçảo do estoque da sardinha Sardinella brasiliensis: uma compilação. Atlântica, Rio Grande, 13(1):29-43.

CERGOLE, M. C. \& BITTENCOURT, M. M. 1988a. Age and growth of the southeastern Brazilian sardine, Sardinella brasiliensis, 1981-83. Bolm Inst. oceanogr., S Paulo, 36(1):17-35.

\& MUNHOZ, M. 1988b. PIEBS - Programa Integrado de Estudos Biologicos sobre a Sardinha. IV- Idade e crescimento. In: SIMPÓSIO DA FURG SOBRE PESQUISA PESOUEIRA, 1., Rio Grande, 1988. Resumos. Rio Grande, Fundação Universidade do Rio Grande. p.45.

SAILA, S. B.; RECKSIEK, C. W. \& PRAGER, M. H. 1988. Basic Fishery Science Programs. A compendium of microcomputer programs and manual of operation. Amsterdam, Elsevier. 230p.

SANTOS, E. P. \& FRATZEN, F. M. 1965. Growth of sardines: quantitative aspects. Anais Acad. bras. Ciênc., 37(supl.):360- 362 .

SPACH, H. L. 1990. Estudo comparativo da distribuição espaço-temporal e de padrōes de agregação de ovos e larvas de Harengula jaguana, Sardinella brasiliensis (Clupeidae: Osteichthyes) e Engraulis anchoita (Engraulidae: Osteichthyes) na costa sudeste do Brasil. Tese de doutorado. Universidade de São Paulo, Instituto Oceanográfico. 87p.

SSENTENGO, G. M. \& LARKIN, P. 1973. Some simple methods of estimating mortality rates of exploited fish populations. J. Fish. Res. Bd Can., 30:695-698.

SUDEPE/PDP. 1985. Relatório da Reunião do Grupo de Trabalho e Treinamento (GTT) sobre Avaliação de Estoques, 2. Sér. Doc. Téc. SUDEPE/PDP, 34:1-439.

VALENTINI, H. \& CARDOSO, R. DE D. 1991. Análise da pesca da sardinha-verdadeira, Sardinella brasiliensis, na costa sudeste-sul do Brasil. Atlântica, Rio Grande, 13(1):45-54. 
VAZZOLER, A. E. A. de M.; ROSSIWONGTSCHOWSKI, C. L. D. B. \& BRAGA, F. M. de S. 1982. Estudos sobre estrutura, ciclo de vida e comportamento de Sardinella brasiliensis (Steindachner, 1879), na área entre $22^{\circ} \mathrm{S}$ e $28^{\circ} \mathrm{S}$, Brasil. II. Determinação da idade individual e crescimento dos otólitos. Bolm Inst. oceanogr., S Paulo, 31(2):77-84.

VAZZOLER, A. E. A. de M.; ROSSIWONGTSCHOWSKI, C. L. D. B. \& BRAGA, F. M. de S. 1987. Estudos sobre estrutura, ciclo de vida e comportamento de Sardinella brasiliensis (Steindachner, 1879), na área entre $22^{\circ} \mathrm{S}$ e $28^{\circ} \mathrm{S}$, Brasil. IV. Crescimento: aspectos quantitativos. Bolm Inst. oceanogr., S Paulo, 35(1):53-63.
VETTER, E. F. 1988. Estimation of natural mortality in fish stocks: a review. Fishery. Bull. natn. Fish. Serv., U.S., 86(1):25-43.

WETHERALL, J. A. 1986. A new method for estimating growth and mortality parameters from length-frequency data. Fishbyte, 4(1):12-15.

(Manuscript received 01 December 1993; revised 29 September 1994; accepted 7 October 1994) 